\title{
Purification and immunological characterization of color carp (Cyprinus carpio) fibroblast heat-shock proteins
}

\author{
C. C. Ku, C. H. Lu, ${ }^{*}$ G. H. Kou and S. N. Chen
}

Department of Zoology, National Taiwan University, Taipei, Taiwan 106, Republic of China; and *Department of Agricultural Chemistry, National Taiwan University, Taipei, Taiwan 106, Republic of China

Eighty-seven, 72 and $30 \mathrm{kDa}$ heat-shock proteins from color carp testis cell line, $\mathrm{CCT}$, were purified, and rabbit antibodies were raised against them. After heat shock at $37^{\circ} \mathrm{C}$, hsp87 appeared mainly in the cytoplasm and hsp72 and hsp30 appeared in the nucleus. When cells were restressed at $37^{\circ} \mathrm{C}$ for $8 \mathrm{hr}$ after three recovery periods, the intensity and localization of the three anti-CCT hsps staining changed from those following an initial stress for $8 \mathrm{hr}$. The anti-CCT hsp87 and hsp72 antibodies crossreacted with proteins of similar molecular weights in all tested fish, lizard, mouse and human cell lines, but they showed various degrees in antigenic relevance.

Key words: Heat-shock proteins; Localization; Hsp87; Crossreaction; Fish cell line; Cyprinus carpio; Fibroblast.

Comp. Biochem. Physiol. 107B, 147-159, 1994.

\section{Introduction}

Heat shock proteins (hsps) are induced when a cell is stressed by various environmental insults including high temperatures, heavy metals, amino acid analogues and exposure to a variety of chemical compounds (Lindquist, 1986). Although these factors do not affect various species equally, the heat-shock response has been shown to occur in many different organisms, ranging from bacteria to plants and up to all higher mammalian tissue, and a number of eukaryotic cell lines. The hsps show remarkable conservation throughout evolution. Nearly all species induce the synthesis of proteins in the size-ranges of $80-90 \mathrm{~K}, 68-74 \mathrm{~K}$ and $18-30 \mathrm{~K}$. Larger proteins appear to be more highly conserved than smaller proteins (Craig, 1985).

Hsp90 represents one of the most abundant proteins in mammalian cells, yet its synthesis still increases after stress (Welch, 1992). It suppresses the formation of protein aggregates

Correspondence to: C. C. Ku, Department of Zoology, National Taiwan University, Taipei, Taiwan 106, Republic of China.

Received 18 May 1993; accepted 6 July 1993 in vitro (Wiech et al., 1992), and serves a regulatory role in the cell by binding to target proteins, such as dioxin receptor (Pongratz et al., 1992), tyrosine kinase PP ${ }^{60 s r c}$, hormone-free steroid receptors, or heme-regulated eukaryotic initiation factor (EIF)2a kinase, and either inhibiting or stimulating their activities (Welch, 1992). Hsp70 has been implicated in facilitating protein-maturation in the presence of ATP (Beckmann et al., 1992), and in contributing to transportation of nuclear proteins through interaction with nuclear location sequences (Imamoto et al., 1992). The small hsps are related to the $\alpha$-crystallines and can form high molecular weight complexes alocated in the perinuclear region (Arrigo et al., 1988; Collier et al., 1988; Nover et al., 1983). Their physiological roles are unknown, although over-expression of hsp27 and hsp25 has been reported to increase the thermotolerance of some mammalian cells (Landry et al., 1989), to become associated with processes involved in differentiation (Stahl et al., 1992), and to inhibit growth of Ehrlich ascites tumor cells (Knauf et al., 1992). In addition to these studies at the biochemical level, these 
stress proteins are being considered for their potential role as sensitive markers of cell injury, for their possible connection with the immune response and autoimmune diseases, and for a new way by which to monitor the status of our environment (Welch, 1992).

The heat-shock response has been studied most thoroughly in Drosophila, in mammalian and avian cells, and in bacteria and yeast. Studies of heat-shock responses in fish cell lines have previously been performed on cells derived from rainbow trout gonad (Salmo gairdnerii) (Kothary and Candido, 1982; Mosser et al., 1986; Misra et al., 1989), chinook salmon embryo (Oncorhynchus tshawytscha) (Heikkila et al., 1982; Gedamu et al., 1983), channel catfish hepatocytes (I. punctatus) (Koban et al., 1987), topminnow hepatocellular carcinoma (Poeciliopsis) (Hightower and Renfro, 1988), tilapia ovary (hybrid of $T$. mossambica and T. nilotica) (Chen et al., 1988), and color carp gill and fin (Cyprinus carpio) $(\mathrm{Ku}$ and Chen, 1991; Ku et al., 1992), or in tissues of goldfish (Sato et al., 1990), medaka (Oryzias latipes) (Oda et al., 1991), and fathead minnow (Pimephales promelas) (Dyer et al., 1991). These studies clearly demonstrate that teleosts can mount a stress response very similar to that observed with other vertebrates. The teleost response can be triggered by several of the same stressors known to induce the response in other organisms. These include heat shock, exposure to heavy metal ion, and sodium arsenite (Hightower and Renfro, 1988; Bols et al., 1992). Drosophila hsp70 cDNA and anti-chicken hsp70 antisera are used to quantify salmon hsp70 mRNA and measure trout hsp70 accumulation separately (Heikkila et al., 1982; Kothary et al., 1984a). At the molecular level, the cDNA of trout hsp70 has been cloned and sequenced; it shows extensive homology with the hsp70 genes of both Drosophila and yeast (Kothary et al., 1984b).

Our previous studies ( $\mathrm{Ku}$ and Chen, 1991; Ku et al., 1992), have shown that cells derived from gill (CCG) and fin (CCF) of color carp are able to synthesize hsp87, hsp70, hsp33 and hsp27 at $40^{\circ} \mathrm{C}$; but at $37^{\circ} \mathrm{C}$ only heat-shock proteins with high molecular weights are synthesized. However, cells derived from testis tissue (CCT) $(\mathrm{Ku}$ and Chen, 1992) of the same species could synthesize hsp87, hsp72, hsp68 and hsp30 at $37^{\circ} \mathrm{C}$. These differences motivated our study that compares hsps in the three cell lines derived from different tissues of the same species.

This paper attempts to describe the immunological characterization of hsps in CCT cell. Immunoprecipitation, one- or two-dimensional polyacrylamide gel electrophoresis (1- or 2-D SDS-PAGE), immunoblotting and indirect im- munofluorescence were used to investigate the isoelectric point (PI), and changes in the quantity and intracellular localization of hsps in CCT cells during heat shock. In addition, we surveyed cell lines derived from fish, lizard, mouse and human for proteins that might crossreact with our anti-CCT hsps antibodies.

\section{Materials and Methods}

\section{Cell culture employed and stress conditions}

The cell lines derived from freshwater fish are CCT, CCG, CCF, TO-2, EO, EK, LF, CHSE214, FHM, EPC, CCO, BF-2, and RTG-2, while BGK, BPS, BPK, JF, MH are from seawater fish (Ku and Chen, 1992; Chen and Kou, 1988; Yoshimizu et al., 1988). Lists of species and of the tissues from which these cell lines were derived are shown in Table 1. Cell lines were maintained in Eagle's MEM or Leibovitz L-15 containing $10 \%$ FCS (Sera-Lab Ltd, U.K.). For stress treatment, equal amounts of cells were seeded to $35-\mathrm{mm}$ petri dishes. After $24 \mathrm{hr}$, the cells were placed in a water bath equipped with a circulating Thermomix 810 (Hotech), or treated with cadmium or arsenite.

\section{Cell labeling and gel electrophoresis}

Cells were labeled in a methionine-free medium with 20 or $100 \mu \mathrm{Ci} / \mathrm{ml}{ }^{35} \mathrm{~S}$-methionine (specific activity $1,209.3 \mathrm{Ci} / \mathrm{mmol}$ ) for the final $2 \mathrm{hr}$ incubation or immediately following the various treatments.

Proteins were solubilized directly in an SDS sample buffer, for 1-D SDS-PAGE (Laemmli, 1970), or in a denature solution for 2-D SDS-PAGE (Hochstrasser et al., 1988). In 1-D SDS-PAGE, samples were electrophoretically analyzed on an SDS-polyacrylamide slab gel in a buffer system of $0.025 \mathrm{M}$ Tris $(\mathrm{pH} 8.8)$, $0.192 \mathrm{M}$ glycine, $0.1 \%$ SDS, and $0.002 \mathrm{M}$ EDTA. In 2-D SDS-PAGE, analysis consisted of isoelectric focusing on an ampholyte gel with a $\mathrm{pH}$ 4-8.5 gradient. The samples were loaded onto the basic end of the gel and subjected to electrophoresis at $200 \mathrm{~V}$ for $2 \mathrm{hr}$, followed by $500 \mathrm{~V}$ for $5 \mathrm{hr}$; and then $800 \mathrm{~V}$ for $16 \mathrm{hr}$. At the end of the run, the gel rods were rinsed with $150 \mu \mathrm{l}$ of transfer solution and transferred to the top of a slab gel consisting of SDSpolyacrylamide (Hochstrasser et al., 1988). After electrophoresis, the gels were dried and exposed to Dupont Cronex X-ray film at $-70^{\circ} \mathrm{C}$ for 6 days. Autoradiographs were developed in a KODARK M35 X-OMAT Processor. In order to compare protein bands intensities, equal sample volumes were loaded into the gel wells. 2-D SDS-PAGE standards (Bio-Rad, Richmond, CA) were run at the same time. 
Table 1. Immune assay of cell lines with antibodies to color carp heat-shock proteins

\begin{tabular}{|c|c|c|c|c|c|}
\hline \multirow[b]{2}{*}{ Cell line } & \multirow{2}{*}{$\begin{array}{l}\text { Growth temp. } \\
\left({ }^{\circ} \mathrm{C}\right)\end{array}$} & \multirow{2}{*}{$\begin{array}{l}\text { Heat treatment } \\
\qquad\left({ }^{\circ} \mathrm{C} / \mathrm{hr}\right)\end{array}$} & \multicolumn{3}{|c|}{ Anti-CCT hsp antibodies } \\
\hline & & & hsp87(I) & hsp72(I\&F) & hsp30(I\&F) \\
\hline \multicolumn{6}{|l|}{ A. Fish } \\
\hline \multicolumn{6}{|l|}{ a. Color carp; Cyprinus carpio } \\
\hline 1. CCT & 31 & $37 / 8$ & +++ & $++t$ & +++ \\
\hline 2. $\mathrm{CCG}$ & 31 & $40 / 8$ & +++ & +++ & - \\
\hline 3. $\mathrm{CCF}$ & 31 & $40 / 8$ & ++ & +++ & - \\
\hline \multicolumn{6}{|c|}{ b. Tilapia; hybrid of mossambica and nilotica } \\
\hline 4. TO-2 ovary & 31 & $37 / 8$ & +++ & +++ & +++ \\
\hline \multicolumn{6}{|c|}{ c. Blue-spotted grouper; Epinephelus faris } \\
\hline $\begin{array}{l}\text { 5. BGK kidney } \\
\text { d. Japanese eel; Anguilla japoni }\end{array}$ & 31 & $40 / 3$ & +++ & +++ & +++ \\
\hline 6. EO Ovary & 31 & $37 / 4$ & +++ & +++ & +++ \\
\hline kidney & 31 & $37 / 4$ & +++ & $+t+$ & +++ \\
\hline \multicolumn{6}{|c|}{ e. Formosa snake-head; Chana maculata } \\
\hline 8. FS swim bladder & 31 & $40 / 5$ & +++ & +++ & +++ \\
\hline \multicolumn{6}{|c|}{ f. Loach; Misgurnus anguillicandatus } \\
\hline 9. LF fin & 31 & $40 / 3$ & ++ & +++ & - \\
\hline \multicolumn{6}{|c|}{ g. Chinook salmon; Oncorhynchus tschawytscha } \\
\hline 10. CHSE-214 embryo & 18 & $28 / 8$ & ++ & +++ & - \\
\hline \multicolumn{6}{|c|}{ h. Fathead minnow; Pimephales promelas } \\
\hline $\begin{array}{l}\text { 11. FHM caudal trank } \\
\text { i. Carp; Cyprinus carpio }\end{array}$ & \multicolumn{5}{|c|}{ i. Carp; Cyprinus carpio } \\
\hline 12. EPC epithelioma & 31 & $37 / 4$ & ++ & $++t$ & - \\
\hline \multicolumn{6}{|c|}{ j. Channel catfish; Ictalurus punctatus } \\
\hline 13. $\mathrm{CCO}$ ovary & 31 & $37 / 4$ & ++ & +++ & - \\
\hline \multicolumn{6}{|l|}{ k. Bluegill; Lepomis macrochirus } \\
\hline 14. BF-2 fry & 24 & $37 / 4$ & ++ & ++ & - \\
\hline \multicolumn{6}{|c|}{ 1. Black porgy; Sparus macrocephalus } \\
\hline 15. BPS spleen & 31 & $37 / 5$ & + & ++ & - \\
\hline 16. BPK & 31 & $37 / 5$ & + & ++ & - \\
\hline \multicolumn{6}{|l|}{ m. Jarbua; Therapon jarbua } \\
\hline 17. JF fin & 31 & $40 / 4$ & + & ++ & - \\
\hline \multicolumn{6}{|l|}{ n. Milkfish; Chanos chanos } \\
\hline 18. MH heart & 31 & $40 / 11$ & + & + & - \\
\hline \multicolumn{6}{|c|}{ o. Rainbow trout; Salmo gairdnerii } \\
\hline 19. RTG-2 & gonad & 18 & $31 / 5$ & + & + \\
\hline \multicolumn{6}{|l|}{ B. Lizard; Japalura mitsukurii } \\
\hline 20. JK kidney & 31 & $40 / 5$ & +++ & +++ & +++ \\
\hline \multicolumn{6}{|l|}{ C. Mouse } \\
\hline 21. $\mathrm{CHO}$ & 37 & $45 / 2$ & + & + & - \\
\hline \multicolumn{6}{|l|}{ D. Human } \\
\hline 22. Hela & 37 & $45 / 2$ & + & + & - \\
\hline 23. $\mathrm{HF}$ & 37 & $45 / 2$ & + & + & - \\
\hline
\end{tabular}

I: observed by immunoblotting.

F: observed by indirect immunofluorescent stain.

\section{Purification of fish heat-shock proteins}

The T-80 flasks of CCT cells were brought to confluence in $\mathrm{L} 15-10$ at $31^{\circ} \mathrm{C}$ and transferred to a $37^{\circ} \mathrm{C}$ water bath. Prior to transfer, the medium in each flask was replaced with $10 \mathrm{ml}$ of L15-10 methionine-free medium with $5 \mu \mathrm{Ci} / \mathrm{ml}{ }^{35} \mathrm{~S}-$ methionine. After $8 \mathrm{hr}$ at $37^{\circ} \mathrm{C}$, all cells were washed with PBS, trypsinized, and analyzed by SDS-PAGE. Gels were dried immediately and exposed to Dupont Cronex X-ray film at $-70^{\circ} \mathrm{C}$ for 6 days. The bands corresponding to hsp87, hsp72 and hsp30 on the autoradiograph were cut from the gels and each was eluted by an electro-eluter (Bio-Rad). The eluted protein was dialyzed against double-distilled water, re- natured with $6 \mathrm{M}$ urea (Liao, 1975) and dialyzed once more in double-distilled water.

\section{Preparations of antibodies}

Pre-immune sera were obtained from twomonth-old female New Zealand rabbits. Purified proteins were mixed in Freund complete adjuvant (Difco Laboratories), and approximately $0.5 \mathrm{mg}$ hsp 87 , hsp 72 or hsp30 were injected subcutaneously. Three weeks after the initial injection, additional protein in incomplete Freund adjuvant was injected. Ten days after this boost, $40-50 \mathrm{ml}$ of serum per rabbit were collected, and the complement system was inactived. Antibodies of hsp 72 or hsp30 were further adsorbed by acetone-dried normal CCT 
cells, clarified by centrifugation, purified by protein A chromatograph and stored at $-70^{\circ} \mathrm{C}$.

\section{Non-denaturing immunoprecipitation}

After labelling, the cells were washed with PBS and lysed in $20 \mathrm{mM}$ Tris, pH $7.5,150 \mathrm{mM}$ $\mathrm{NaCl}, 0.5 \%$ NP- $40,0.5 \%$ deoxycholate, $0.1 \%$ SDS (RIPA buffer). The cell lysates were clarified by centrifugation. The cleared lysates were incubated with the anti-CCT hsp antibodies at $4{ }^{\circ} \mathrm{C}$ with gentle rocking for $1 \mathrm{hr}$. Protein A-agarose beads were added and the incubation continued for $1 \mathrm{hr}$. The immunoprecipitates were washed five times with an RIPA buffer, and the precipitated proteins were released from the bead by the addition of SDS-gel electrophoresis sample buffer followed by the boiling for $5 \mathrm{~min}$. The immunoprecipitates were analyzed by SDS-PAGE.

\section{Immunoblotting}

Following electrophoresis, proteins were transferred with a Hoeffer electrotransphor apparatus to Immobilon PVDF Transfer Membranes (Millipore) for $1 \mathrm{hr}$ at $1 \mathrm{~A}$, then blocked with $3 \%$ skim milk (Difco) in TBS (20 mM Tris, $500 \mathrm{mM} \mathrm{NaCl}$, pH 7.5) for $1 \mathrm{hr}$ at room temperature. The rabbit anti-CCT hsp antibody was used at a dilution of $1: 100$ in 3\% skim milk-TBS for $1 \mathrm{hr}$; these were rinsed three times in TBS containing $0.05 \%$ Tween 20 (10 min per wash), incubated for $1 \mathrm{hr}$ with a 1:10,000 dilution of peroxidase-conjugated goat anti-rabbit antibody (Jackson Immunore- search), rinsed three times as before, then reacted with 4-chloro-1-naphtol (Merck).

\section{Indirect immunofluorescence}

About $10^{5}$ cells were plated directly onto a $35-\mathrm{mm}$ petri dish and allowed to adhere for at least $24 \mathrm{hr}$. The cells were fixed in $3.7 \%$ paraformaldehyde in PBS for $10 \mathrm{~min}$, followed by immersion in $0.2 \%$ Triton X-100 in PBS for 2 min plus a PBS wash. The rabbit anti-CCT hsp antibody was used at a dilution of 1:500 in $3 \%$ BSA and incubated with cells for $1 \mathrm{hr}$ at room temperature. Cells were rinsed with PBST (containing $0.05 \%$ Tween 20 ) and incubated for $1 \mathrm{hr}$ with a 1:20 dilution of fluorescein isothiocyanate-conjugated goat anti-rabbit immunoglobulin G (Jackson Immunoresearch). The dishes were then rinsed, mounted in phosphate-buffered glycerol, and observed with a microscope equipped with epifluorescence optics. Samples were photographed with Kodak $35-\mathrm{mm}$ Tri-X film shot at 400 ASA for $50 \mathrm{sec}$.

\section{Results}

CCT is a fibroblast cell line derived from testis tissue of color carp (Cyprinus carpio) and cultured at $31{ }^{\circ} \mathrm{C}$ routinely. When cultured at $37^{\circ} \mathrm{C}$, proliferation was gradually reduced; cells lost their normal shape, becoming flattened, and many phase-dense perinuclear granules were contained in the cytoplasm.

Change in the protein synthesis pattern of CCT cells after heat shock is shown in Fig. 1.
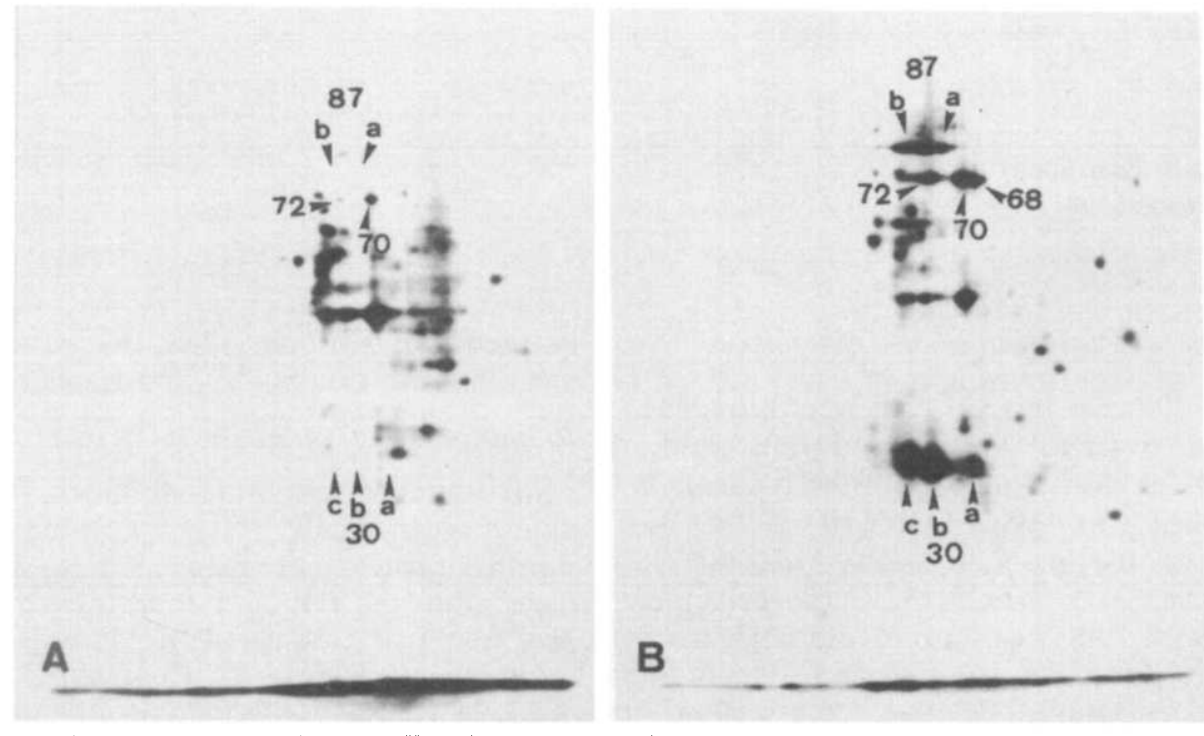

Fig. 1. Two-dimensional gel analysis of CCT cells. CCT cells grown on $35-\mathrm{mm}$ plastic dishes were labeled with $100 \mu \mathrm{Ci} / \mathrm{ml}{ }^{35} \mathrm{~S}$-methionine at $31{ }^{\circ} \mathrm{C}$ (A) and at $37^{\circ} \mathrm{C}$ (B) for $6 \mathrm{hr}$. The cells were lysed and two-dimensional electrophoresis carried out. The $\mathrm{pH}$ range of the first dimension of isoelectric focusing was 4-8.5 from left to right, and the migration in the second dimension of SDS-PAGE was from top to bottom. The autoradiographs of the gels are shown. The locations of major hsp $(87,72,30)$ are identified in the autoradiographs. 
Analysis on 2-D SDS-PAGE of the labeled polypeptides under normal growth conditions (Fig. 1A) and after a heat treatment of $37^{\circ} \mathrm{C}$ for $6 \mathrm{hr}$ (Fig. 1B) revealed three major groups of hsps. They were hsp87 (hsp87a, pI =5.5 and hsp87b, pI = 5.1), hsp72 (hsp72, pI = 5.5; hsp70, $\mathrm{pI}=5.6$ and hsp68, $\mathrm{pI}=5.7)$, and hsp30 (hsp30a, pI = 5.7; hsp30b, pI = 5.5 and hsp30c, $\mathrm{pI}=5.2$ ). As can be seen from Fig. 1A, the constitutively expressed hsp70 (hereafter called the heat-shock cognate protein 70, hsc70) was synthesized at a significant level under normal growth conditions, but its synthesis was especially induced after heat shock.

The kinetics of hsps synthesis after or during heat shock at $37^{\circ} \mathrm{C}$ were investigated by $1-\mathrm{D}$ SDS-PAGE. Figure 2 shows hsp87, hsp72, hsp68 and hsp30 enhanced after 5 min of treatment. Hsp87 and hsp72 reached their maximum synthetic rates after $5 \mathrm{~min}$ of treatment; however, the hsp68 and hsp30 required $60 \mathrm{~min}$ to reach their maximum rate. In addition, Fig. 3 shows that hsp97 synthesis was enhanced from 2 to $4 \mathrm{hr}$, reached its maximum rate between 4 and $6 \mathrm{hr}$, and then declined. The hsp87 and hsp68 were continuously enhanced during the experimental period. Hsp27 was enhanced and

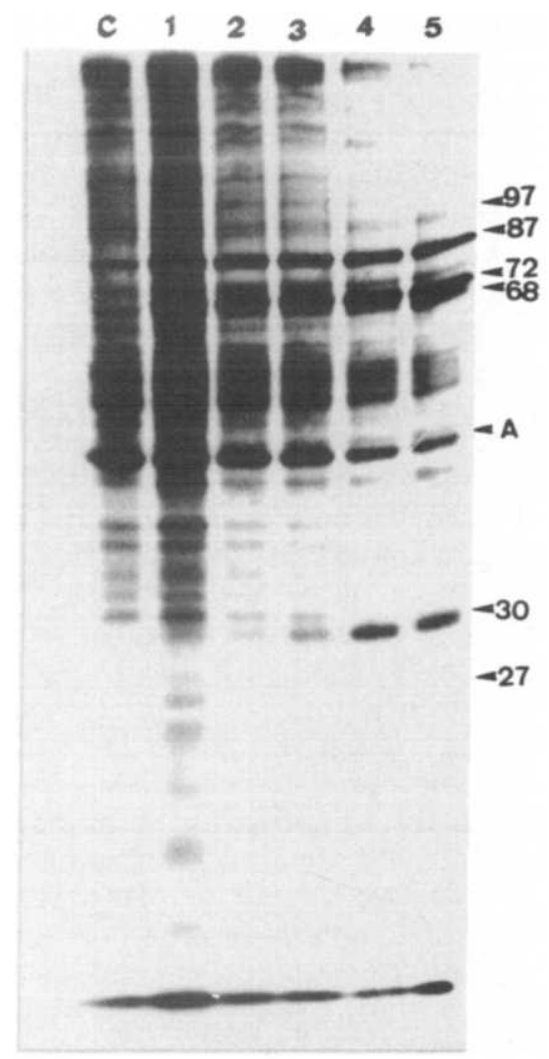

Fig. 2. Autoradiograph showing the enhanced synthesis of hsps after heating at $37^{\circ} \mathrm{C}$. CCT cells were heated at $37^{\circ} \mathrm{C}$ for $0(\mathrm{C}), 5(1), 10(2), 15(3), 30(4), 60 \mathrm{~min}(5)$, then labeled with $20 \mu \mathrm{Ci} / \mathrm{ml}{ }^{35} \mathrm{~S}$-methionine for $2 \mathrm{hr}$ at $31^{\circ} \mathrm{C}$.

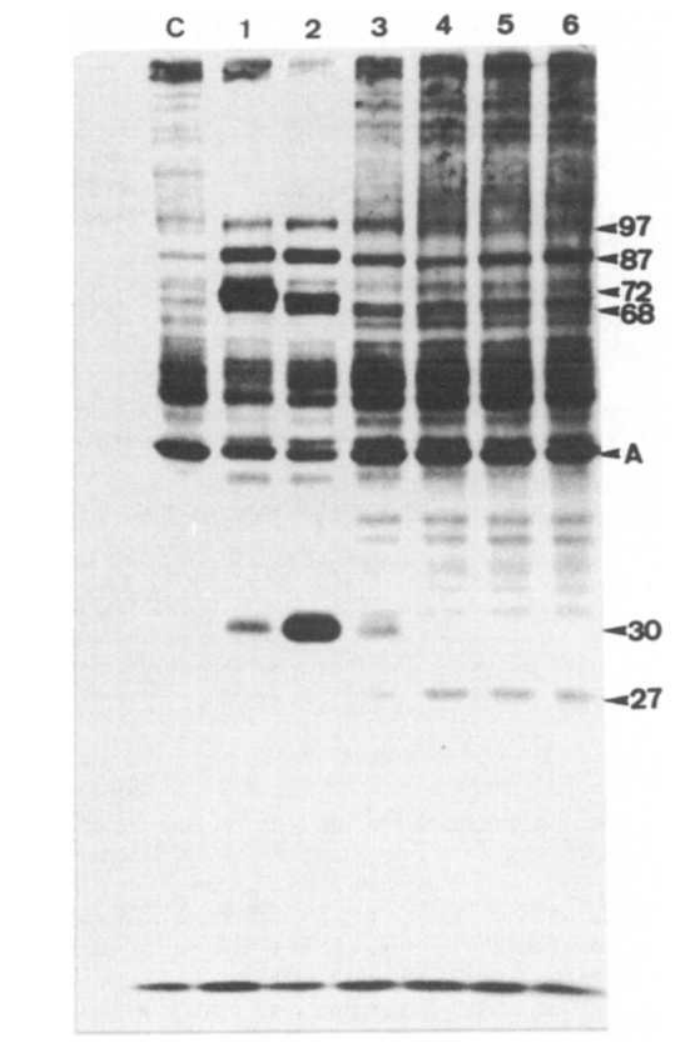

Fig. 3. Autoradiograph showing enhanced synthesis of hsps during heating at $40^{\circ} \mathrm{C}$. CCT cells were labeled with $20 \mu \mathrm{Ci} / \mathrm{ml}^{35} \mathrm{~S}$-methionine for $2 \mathrm{hr}$ at $31{ }^{\circ} \mathrm{C}$ (C) or labeled at $37^{\circ} \mathrm{C}$ from 0 to $2(1), 2$ to $4(2), 4$ to $6(3), 6$ to $8(4), 8$ to $10(5), 10$ to $12 \mathrm{hr}(6)$, respectively.

reached its maximum synthetic rate after $8 \mathrm{hr}$. The most apparent and intense synthesis was achieved in hsp 72 and hsp30, and they ceased to be synthesized after 4 and $6 \mathrm{hr}$, respectively.

Purified hsp87, hsp72 and hsp30 antigens were used to raise antibodies in rabbits, and the antibodies were purified by affinity chromatography. Immunoprecipitation from the lysate of ${ }^{35} \mathrm{~S}$-methionine-labeled CCT cells with the antiCCT hsp antibodies showed the anti-CCT hsp87, hsp 72 and hsp30 antibody to be specific primarily for hsp87, hsp72 and hsp30, respectively (Fig. 4). The same result can be seen on immunoprecipitation of 2-D SDS-PAGE of the CCT cells. Figure 5 shows two hsp87-reaction bands, a set of hsp70 family, and three hsp30 spots were brought down by hsp87, hsp 72 and hsp30, respectively. Immunoblotting further demonstrated the specificity of these antibodies (Fig. 6). Hsp87 was detected under normal conditions, and showed a minor crossreaction with polypeptides of relative molecular mass $102,99,94$ and 70 (hsc70) $\mathrm{kDa}$, as measured by SDS-PAGE. Hsp72, hsp68 and hsp30 were not detected at normal growth temperatures. However, except for the hsp72, rabbit anti-CCT hsp 72 showed a crossreaction to hsp68, and 


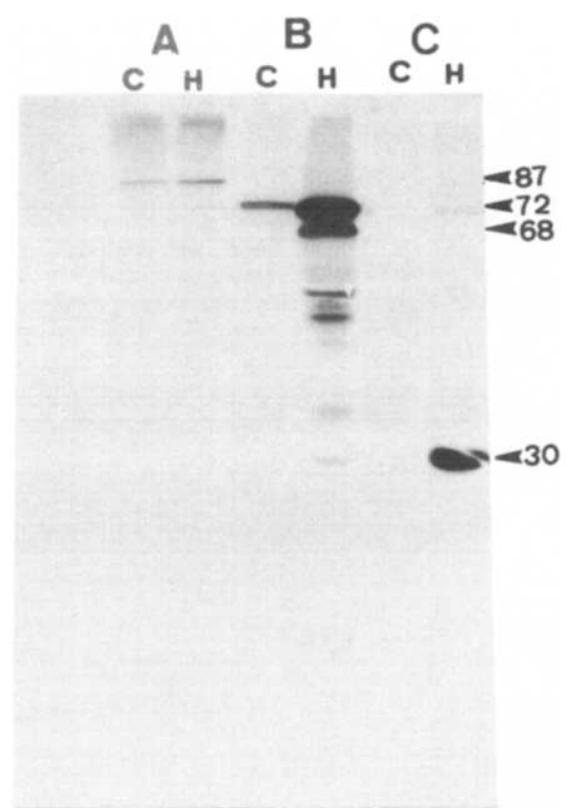

Fig. 4. Immunoprecipitation analysis on one-dimensional SDS-PAGE of anti-CCT hsps antiserum. CCT cells grown on $35-\mathrm{mm}$ plastic dishes were labeled with $20 \mu \mathrm{Ci} / \mathrm{ml}{ }^{35} \mathrm{~S}$ methionine at $31^{\circ} \mathrm{C}(\mathrm{C})$ and at $37^{\circ} \mathrm{C}(\mathrm{H})$ for $6 \mathrm{hr}$. Cells were washed with PBS and solubilized in RIPA buffer. Immunoprecipitates were incubated with anti-hsp87 (A), anti-hsp72 (B) and anti-hsp30 (C) antiserum, respectively, as described under Materials and Methods. After immunoprecipitation the immunocomplexes were analyzed on $7 \%(\mathrm{~A}$ and $\mathrm{B})$ or $12 \%$ (C) SDS-PAGE. The autoradiograph of the gel is shown.

hsc70 which was present at detectable levels in both control and heat-shock cells.

The anti-CCT hsp antibodies were used to measure the accumulation of hsps in CCT cells during prolonged heat shock at $37^{\circ} \mathrm{C}$. Figure 7 shows that hsp87 and hsc70, (but not hsp30), existed at normal conditions. Hsp87 reached its maximum levels after $6 \mathrm{hr}$ heat shock, and was thereafter maintained during the experimental period (Fig. 7A). Hsp72 levels were detected after $1 \mathrm{hr}$ heat shock, and thereafter maintained a steady-state level during the experimental period (Fig. 7B). Hsp30 levels were evident at $2 \mathrm{hr}$, reached their maximum levels at $12 \mathrm{hr}$, then declined clearly after $24 \mathrm{hr}$ (Fig. 7C).

In order to extend our studies of these hsps in CCT cells, and to seek a function for these proteins, CCT cells were incubated at $37^{\circ} \mathrm{C}$ for varying lengths of time, allowed to recover, then restressed directly, fixed, and examined. The intracellular distribution of these proteins was determined by indirect immunofluorescence.

As expected from immunoblotting, antihsp87 staining was present in non-stressed cells and was localized to the cytoplasm (Fig. 8A and E). After stress, intense cytoplasmic staining with a slight staining of the nucleus was observed (Fig. 8B and C). However, after a $24-\mathrm{hr}$ stress (Fig. 8D) anti-hsp87 staining appeared distributed throughout the cell except within the nucleoli. In cells not given any type of stress, a uniform light staining pattern was detected with anti-hsp 72 antibodies (Fig. 9A and E), indicating that a basal level of immunologically related cognate protein, hsc70, in CCT cells could also be observed by indirect immunofluorescence. In contrast, intense anti-hsp 72 nuclear staining with prominent staining of the nucleoli and a slight increase in the cytoplasmic staining began to appear in the vast majority of 3-hr heatshocked cells (Fig. 9B). By the 6th (Fig. 9C) or 8th hr (Fig. 9I), nuclear staining was observed to be as strong as that of the nucleoli. These cell-staining conditions were disappeared after $24 \mathrm{hr}$ heat-shock treatment (Fig. 9D). Staining of hsp 30 was very weak in non-stressed CCT cells (Fig. 10A and E). Following heat-shock treatment for $3 \mathrm{hr}$ (Fig. 10B) hsp30 appeared distributed throughout the cell. After a $6-\mathrm{hr}$ (Fig. 10C) or 8-hr (Fig. 10I) heat-shock treatment, we observed intense hsp30 nuclear staining. However, by $24 \mathrm{hr}$ (Fig. 10D), hsp30 nuclear staining was degraded, and prominent granules were observed in the cytoplasm. Evidence of three stainings in all gradually disappeared following the recovery periods.

When the 8-hr heat-shocked cells were allowed to recover at $31^{\circ} \mathrm{C}$ for 8,16 and $24 \mathrm{hr}$ respectively, we observed anti-hsp87 (Fig. 8F, G and $H$ ) and anti-hsp72 staining (Fig. 9F, G and H) distributed throughout the cytoplasm. However, anti-hsp30 staining appeared distributed throughout the cell after an 8-hr recovery (Fig. 10F), exclusively in the cytoplasm after a 16-hr recovery (Fig. 10G), and only a few cells with the cytoplasmic aggregates were observed after a $24-\mathrm{hr}$ recovery (Fig. $10 \mathrm{H}$ ).

When the 8-hr, 16-hr and 24-hr recovered CCT cells were subjected to a second $37^{\circ} \mathrm{C}$ for $8 \mathrm{hr}$, we observed hsp87 distributed throughout the cell except within the nucleoli (Fig. 8J, K, L). This pattern contrasted with the distribution of hsp87 after an initial stress at $37^{\circ} \mathrm{C}$ for $8 \mathrm{hr}$ (Fig. 8I), where the protein appeared distributed primarily in the cytoplasm, but was consistent with the distribution of hsp87 after stress at $37^{\circ} \mathrm{C}$ for $24 \mathrm{hr}$ (Fig. 8D). While the 8-hr recovered CCT cells were subjected to a second $37^{\circ} \mathrm{C}$ heat shock for $8 \mathrm{hr}$, hsp72 was primarily distributed in the cytoplasm with some concentrations in the nuclei (Fig. 9J). However, in the 16-hr (Fig. 9K) and 24-hr (Fig. 9L) recovered cells, anti-hsp72 staining appeared distributed primarily in the nucleus. When cells were allowed to restress for $8 \mathrm{hr}$ after each recovery period as described above, hsp30 was exclusively distributed in the cytoplasm (Fig. 10J, K and $\mathrm{L}$ ). 


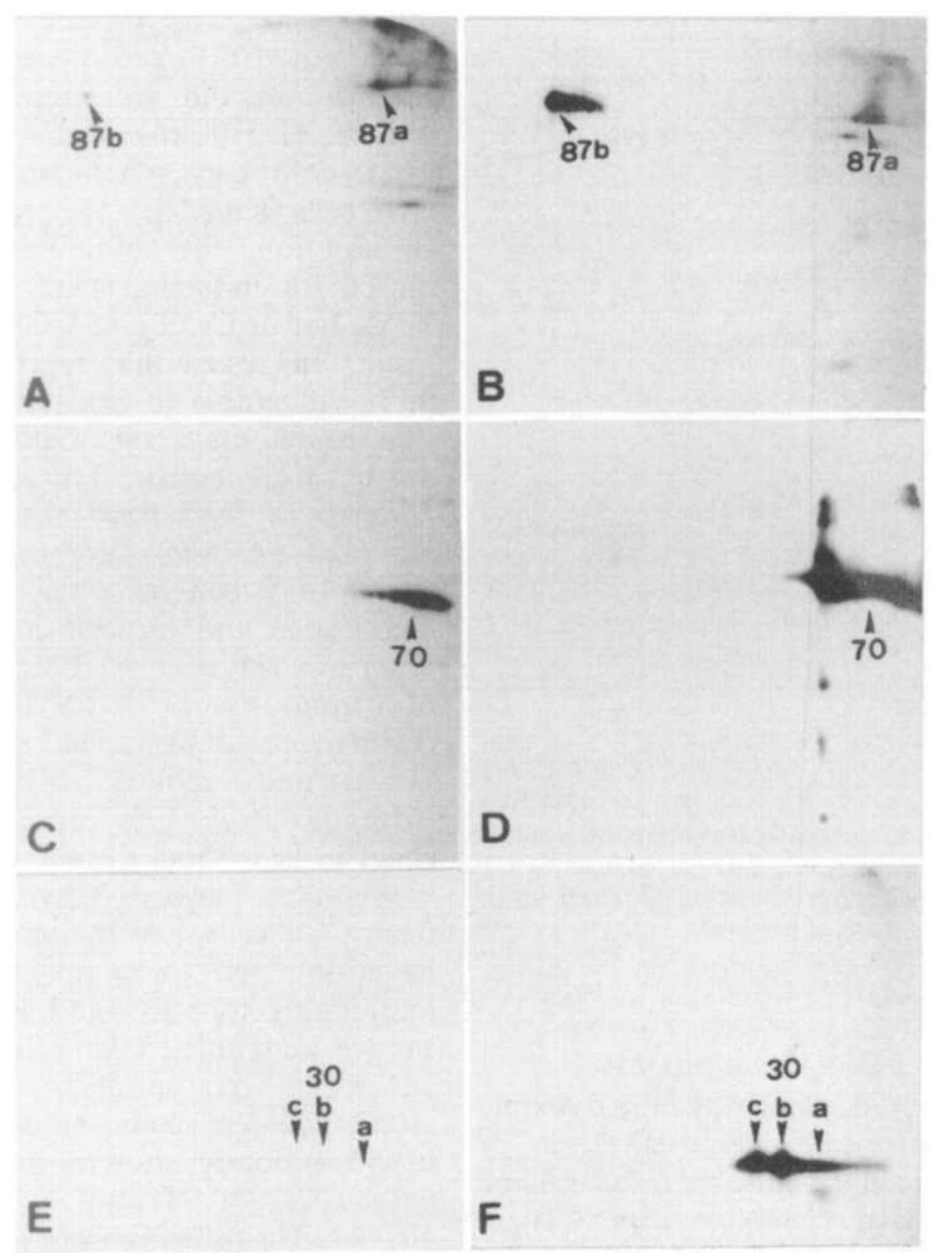

Fig. 5. Immunoprecipitation analysis on two-dimensional gels of anti-CCT hsps antiserum. CCT cells grown on $35-\mathrm{mm}$ plastic dishes were labeled with $100 \mu \mathrm{Ci} / \mathrm{ml}{ }^{35} \mathrm{~S}$-methionine at $31^{\circ} \mathrm{C}(\mathrm{A}, \mathrm{C}, \mathrm{E})$ and at $37^{\circ} \mathrm{C}$ $(B, D, F)$ for $6 \mathrm{hr}$. Cells were washed with PBS and solubilized in a RIPA buffer. Immunoprecipitates were incubated with anti-hsp87 (A, B), anti-hsp72 (C, D) and anti-hsp30 (E, F) antiserum, respectively, as described under Materials and Methods. After immunoprecipitation, the immunocomplexes were analyzed in the first dimension by isoelectric focusing, followed by SDS-PAGE on a $12 \%$ polyacrylamide gel. The acidic end is to the left. The autoradiographs of the gels are shown.

Since a number of other environmental stresses have been shown to induce heat shock or stress proteins in other systems, we examined whether exposure to sodium arsenite and cadmium could induce a set of stress proteins in a CCT cell line similar to that found with heat shock. Figure 11 shows that hsp87, hsp72, hsp 68 and hsp30 were induced by arsenite concentrations ranging from 12.5 to $100 \mu \mathrm{M}$ for $1 \mathrm{hr}$ in CCT cells. In addition, the dynamics of quantity and localization in CCT cells after arsenite were similar to those of heat shock (data not shown). However, synthesis of cadmium-induced hsps was not detected up to $100 \mu \mathrm{M}$ for $1 \mathrm{hr}$ (figure not shown).

Finally, we were interested to determine whether there were heat-shock proteins in other cell lines that could crossreact with our anti-CCT hsp antibodies. We used immunoblot- ting and/or indirect immunofluorescence to examine cells that had been subjected to heat shock. Table 1 lists results of this survey with 18 fish cell lines derived from widely different fish species, one tilapia cell line, one mouse cell line and two human cell lines. Both antiCCT hsp87 and hsp72 antibodies showed crossreactions with proteins of similar molecular weights in all tested cell lines, though of varying degrees in antigenic relevance. However, the anti-CCT hsp30 antibody was only specific for seven cell lines. Additionally, immunofluorescence microscopy using anti-CCT hsp30 antibody strongly reacted with spheroidal bodies present in the cytoplasm of the CCG and LF cells, but did not present a pattern in which the stain was distributed clearly in the cytoplasm or nucleus of stressed cells (figure not shown). 


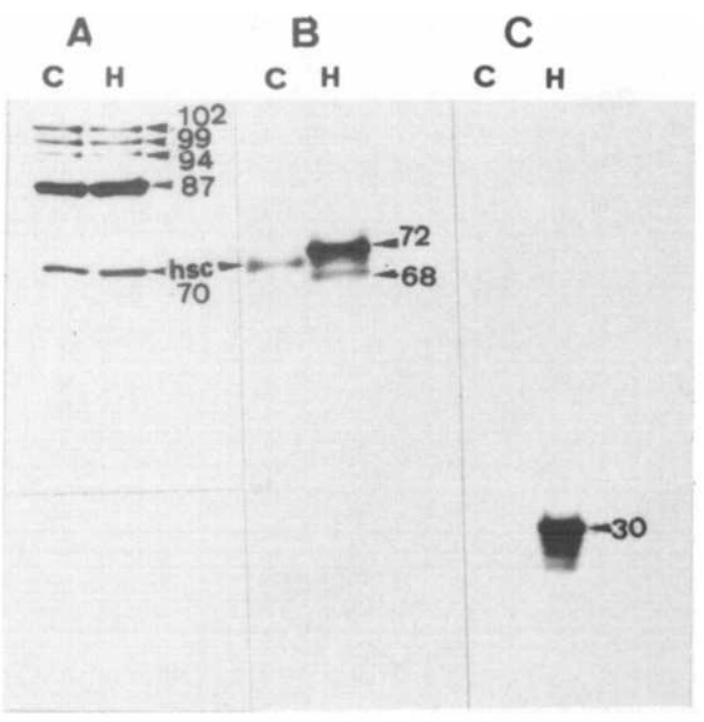

Fig. 6. Immunoblot analysis of the anti-CCT hsps antiserum. (C) control and $(\mathrm{H})$ heat-shocked $\left(37^{\circ} \mathrm{C}, 6 \mathrm{hr}\right) \mathrm{CCT}$ cells were analyzed on $7 \%$ (A and $\mathrm{B}$ ), or $12 \%(\mathrm{C})$ SDS-PAGE and were subsequently transferred to a nitrocellulose sheet. The sheets were incubated with anti-CCT hsp87, hsp72, and hsp30, respectively, as described under Materials and Methods.

\section{Discussion}

The present study demonstrates the dynamic changes in the quantity and localization of heat-shock proteins in the cultured testis cell line (CCT) of color carp Cyprinus carpio. These studies have shown that CCT can produce a stress response very similar to that observed in

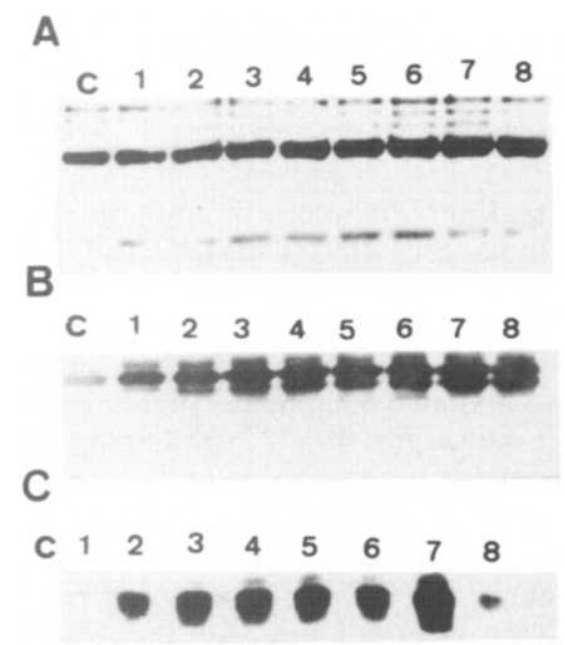

Fig. 7. Immunoblot analysis of induced hsps in CCT heat-shocked cells. Cells were heated at $37^{\circ} \mathrm{C}$ for $0(\mathrm{C}), 1(1)$, 2 (2), 3 (3) 4 (4), 5 (5), 6 (6), 12 (7), $24 \mathrm{hr}(8)$. The proteins were analyzed on $7 \%$ (A and B) or $12.5 \%$ (C) SDS-PAGE and were subsequently transferred to a nitrocellulose sheet. The sheets were incubated with anti-hsp87 (A), anti-hsp 72 (B) and anti-hsp30 (C), respectively, as described under Materials and Methods. other vertebrates (Welch, 1992). Moreover, hsp30 in CCT cells contained methionine residue, and did not present at normal conditions. Hsp30 was probably a tissue-specific hsp in color carp, when compared to CCG and CCF cells (Ku et al., 1992; Ku and Chen, 1991). In addition, the minimum temperatures required for inducing small hsps in CCT were $37^{\circ} \mathrm{C}$, but in $\mathrm{CCG}$ and $\mathrm{CCF}$ were $40^{\circ} \mathrm{C}$. These results suggested that reproductive tissue was more vulnerable to heat-induced damage, and that hsp30 may contribute to cell-protection during heat stress. Tissue-specific induction patterns of hsps have also been reported in mollusc (Aplysia californica), rat (Rattus norvegicus), American cockroach (Periplaneta americana) and fathead minnow (Pimephales promelas) (Dyer et al., 1991). However, studies of various tissues of the lungless salamander (Desmognathus ochrophaeus) (Rutledge et al., 1987) and mollusc (Modiolus japonica) (Margulis et al., 1989) do not show any differences in heat-shock response.

We have purified hsp87, hsp 72 and hsp 30 from CCT cells, and by immunizing rabbits we have obtained three polyclonal antisera. By immunoprecipitation and immunoblotting assay we were able to demonstrate that the three antibodies were specific for the hsp87, hsp72 and hsp30 separately. However, the anti-CCT hsp87 antibody showed minor crossreactions with $102,98,94$ and $70 \mathrm{kDa}$ proteins. The $102-94 \mathrm{kDa}$ proteins were probably steroid receptors associated with hsp90 (Sanchez et al., 1985). The $70 \mathrm{kDa}$ protein is hsp 70 which is found in co-purifying hsp90 taken from several tissue sources (Smith et al., 1992). Furthermore, after immunoprecipitation of 2-D electrophoresis, the hsp87 appeared to consist of two polypeptide isoforms of similar mass and $\mathrm{pI}$ values (Fig. 4). Similar results were obtained by Ullrich et al. (1986) and Welch (1992), who indicated that hsp 87 is encoded by at least two genes, designated $\alpha$ and $\beta$, that appear about $70 \%$ related at the protein sequence level.

When cells were restressed at $37^{\circ} \mathrm{C}$ for $8 \mathrm{hr}$ after three recovery periods, the intensity and localization of the anti-CCT hsp87, hsp72 and hsp30 staining changed from those following an initial stress for $8 \mathrm{hr}$ (Figs 5, 6 and 7). These phenomena suggest that the synthesis and intracellular location of the three proteins in CCT depend on the physiological states of the cell. Similar suggestions are proposed for yeast grown in glucose or in an early stationary phase (Rossi and Lindquist, 1989), which indicates that the different localization patterns of small hsp were obtained simply because the cells used were in different metabolic states. In addition, 

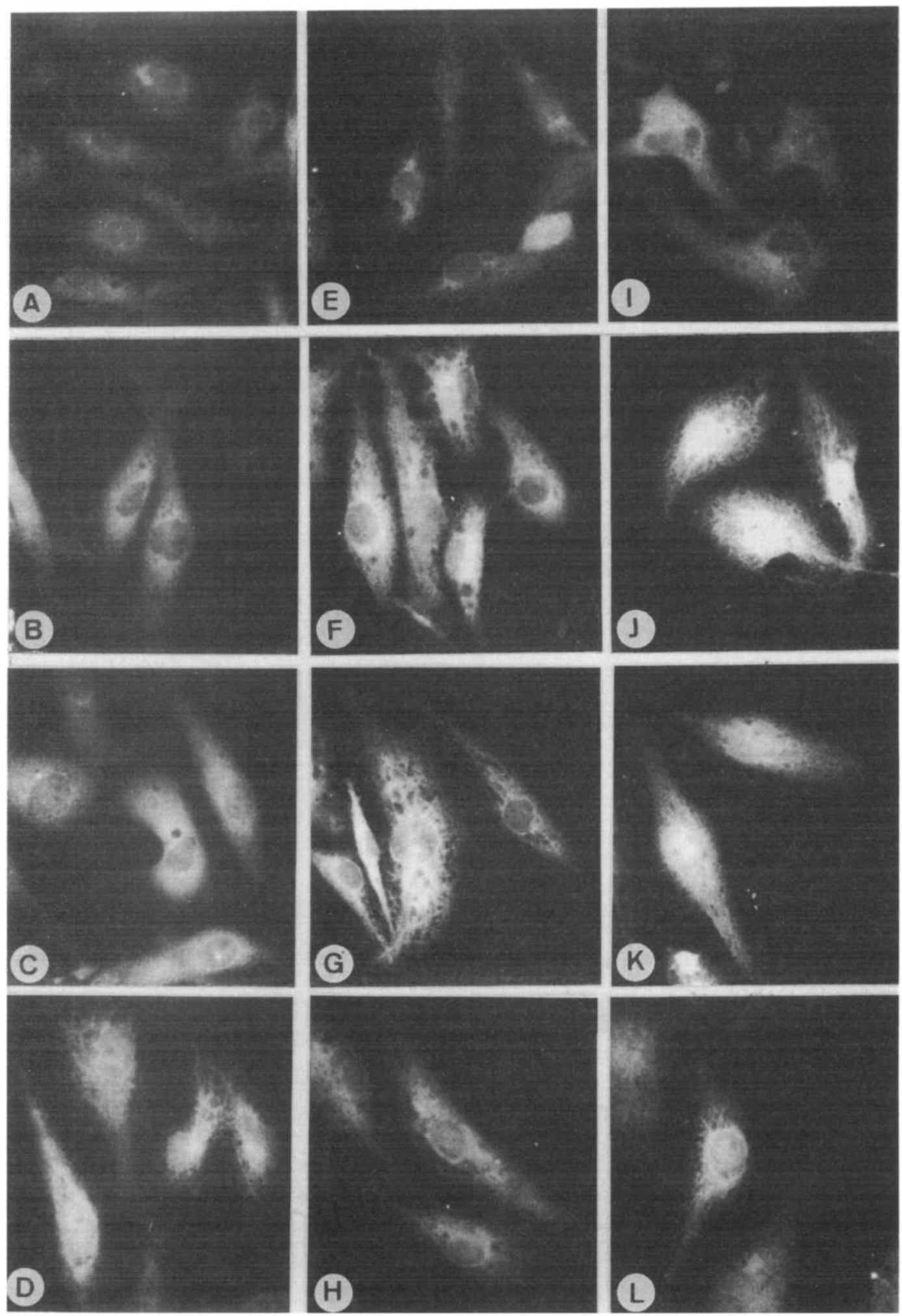

Fig. 8. Dynamic distribution of hsp87 during heat shock, recovery, and restressing of cells. CCT cells were heat shocked at $37^{\circ} \mathrm{C}$ for 0 (A, E), 3 (B), 6 (C), 8 (I), $24 \mathrm{hr}$ (D). The 8-hr heat-shocked cells (I) were allowed to recover at $31^{\circ} \mathrm{C}$ for $8(\mathrm{~F}), 16(\mathrm{G})$ and $24 \mathrm{hr}(\mathrm{H})$ respectively. These recovered cells were subjected to a second heat shock at $37^{\circ} \mathrm{C}$ for $8 \mathrm{hr}$, respectively $(\mathrm{J}, \mathrm{K}$, and L). Cells were fixed with $3 \%$ paraformaldehyde, permeabilized with $0.2 \%$ Triton X-100 and stained with rabbit anti-CCT hsp 87 antibody. $\times 370$. 


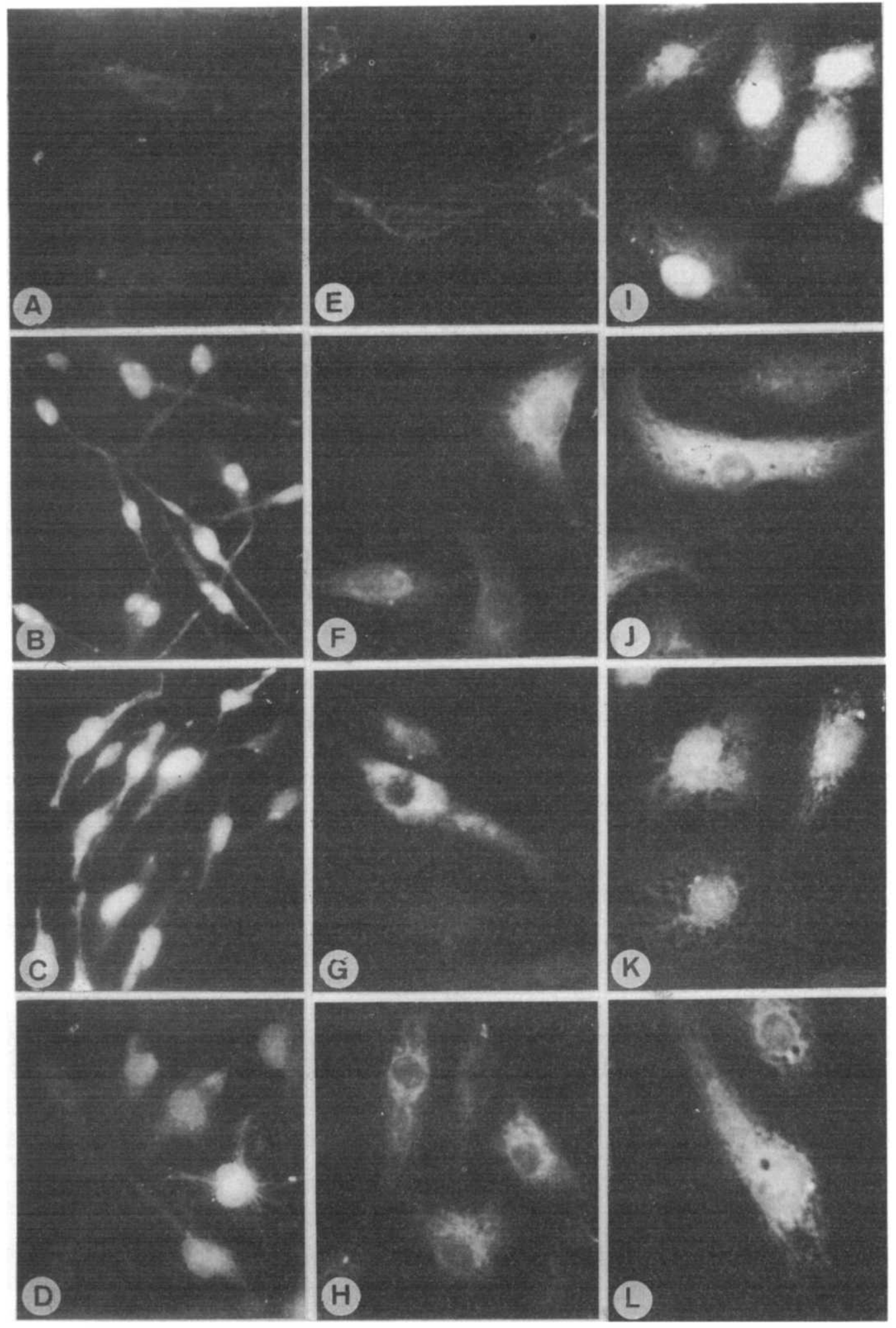

Fig. 9. Dynamic distribution of hsp72 during heat shock, recovery, and restressing of cells. CCT cells were heat shocked at $37^{\circ} \mathrm{C}$ for 0 (A, E), 3(B), 6(C), 8 (I), $24 \mathrm{hr}$ (D). The 8-hr heat-shocked cells (I) were allowed to recover at $31^{\circ} \mathrm{C}$ for $8(\mathrm{~F}), 16(\mathrm{G})$ and $24 \mathrm{hr}(\mathrm{H})$ respectively. These recovery cells were subjected to a second heat shock at $37^{\circ} \mathrm{C}$ for $8 \mathrm{hr}$, respectively, (J, K, and L). Cells were fixed with $3 \%$ paraformaldehyde, permeabilized with $0.2 \%$ Triton X-100 and stained with rabbit anti-CCT hsp 72 antibody. $\times 370$. 


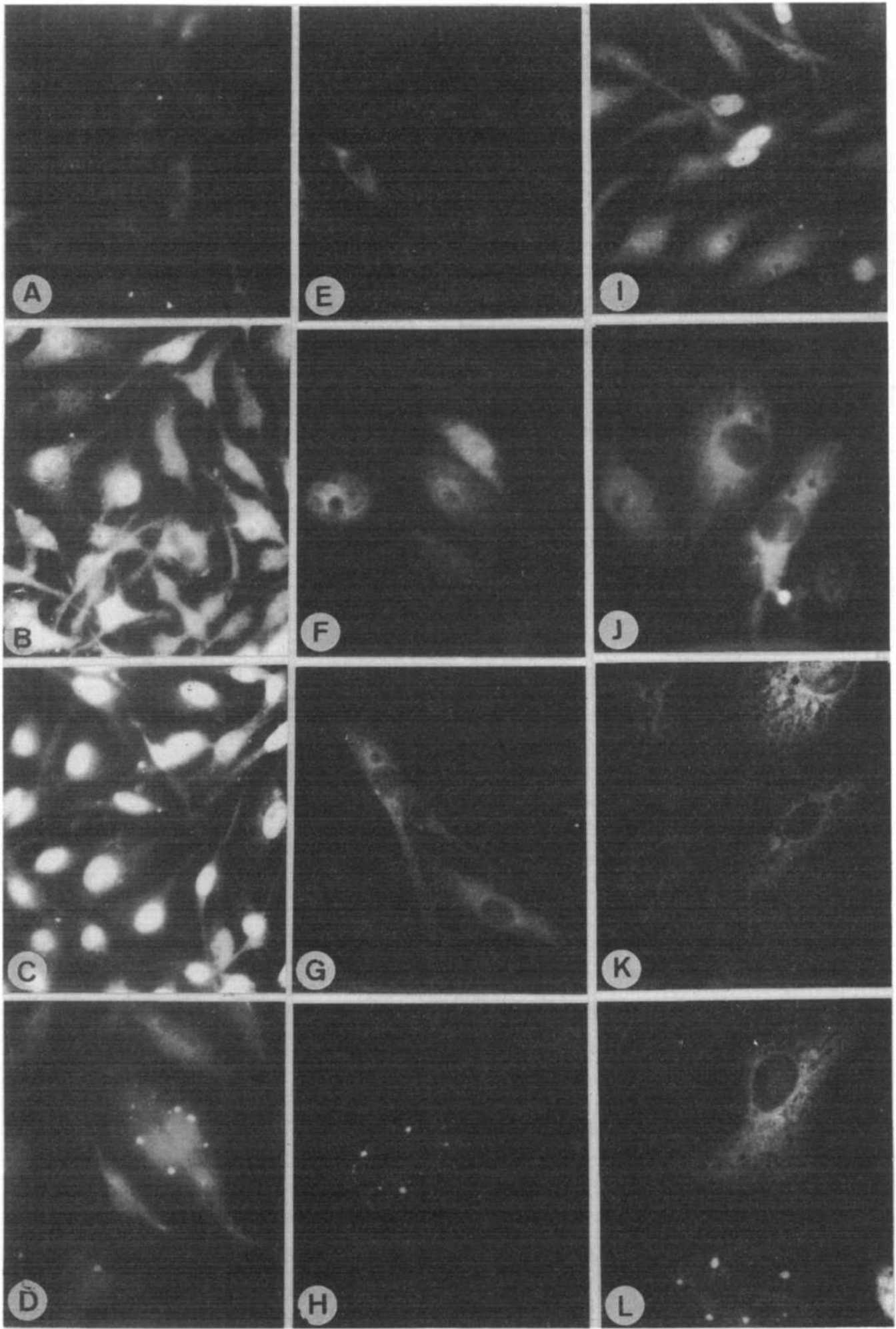

Fig. 10. Dynamic distribution of hsp30 during heat shock, recovery, and restressing cells. CCT cells were heat shocked at $37^{\circ} \mathrm{C}$ for 0 (A, E), 3 (B), 6 (C), 8 (I), $24 \mathrm{hr}$ (D). The 8-hr heat-shocked cells (I) were allowed to recover at $31^{\circ} \mathrm{C}$ for $8(\mathrm{~F}), 16(\mathrm{G})$ and $24 \mathrm{hr}(\mathrm{H})$ respectively. These recovered cells were subjected to a second heat shock at $37^{\circ} \mathrm{C}$ for $8 \mathrm{hr}$, respectively, (J, K, and L). Cells were fixed with $3 \%$ paraformaldehyde, permeabilized with $0.2 \%$ Triton X-100 and stained with rabbit anti-CCT hsp30 antibody. $\times 370$. 


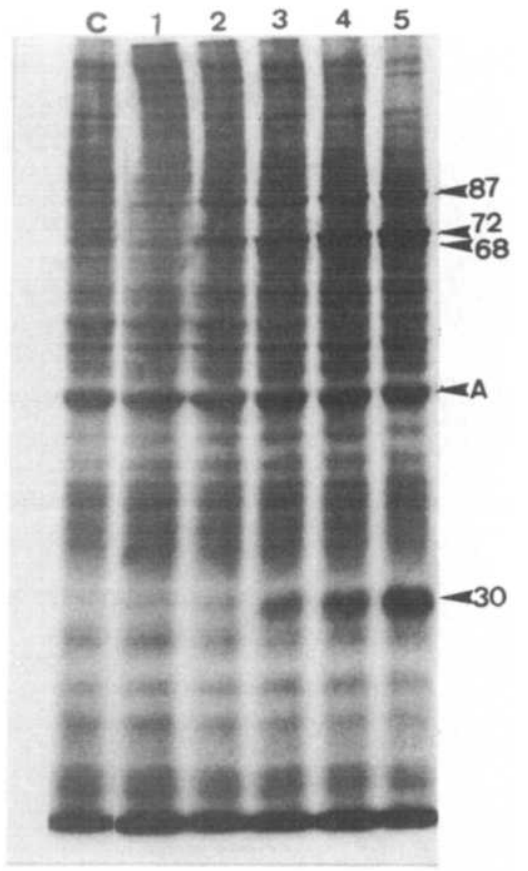

Fig. 11. Autoradiograph showing the induction of stress proteins by arsenite. CCT cells were exposed to 0 (C), 6.25 (1), 12.5 (2), 25 (3), 50 (4) or $100 \mu \mathrm{M}$ (5) of arsenite for $1 \mathrm{hr}$. After being washed, cells were labeled with ${ }^{35} \mathrm{~S}$-methionine for $2 \mathrm{hr}$ at $31^{\circ} \mathrm{C}$. The proteins synthesized $2 \mathrm{hr}$ after stress were analyzed by $10 \%$ SDS-PAGE.

the small hsp is observed to assume different forms depending on the physiological state of the cell (Arrigo et al., 1988). The restressed pattern contrasted with the distribution of hsp87 after an initial stress was observed in the CEF cells (Collier and Schlesinger, 1986), and contradictory results were observed in five mammalian cells (Berbers et al., 1988). Both of these observations strengthen our suggestion. Antibodies raised in rabbit against CCT hsp87 or hsp72 crossreacted with proteins of similar molecular weights in fish, reptile, mouse and human. The data provide further evidence for the universality of the heat-shock response and conservation of proteins induced by this type of stress. However, there existed various degrees in antigenic relevance between these species.

The antibody obtained by CCT hsp 30 showed low crossreaction with protein in CCG cells and none in CCF, although both are derived from the same fish of the same species of CCT $(\mathrm{Ku}$ and Chen, 1992). TO-2, BGK, EO, EK, FS and JK, however, showed strong crossreactions in the immunoassay. These results suggest that the characteristic of small hsp are independent of derived species or even of tissue, but might be related to the natural environment in which the organism lives.

\section{References}

Arrigo A. P., Suhan J. P. and Welch W. J. (1988) Dynamic change in the structure and intracellular locale of the mammalian low-molecular-weight heat shock protein. Molec. Cell Biol. 8, 5059-5071.

Berbers G. A. M., Kunnen R. and van Bergen P. M. P. (1988) Localization and quantitation of hsp84 in mammalian cells. Exp. Cell Res. 177, 257-271.

Beckmann R. P., Lovett M. and Welch W. J. (1992) Examining the function and regulation of hsp 70 in cell subjected to metabolic stress. J. Cell Biol. 117, 1137-1150.

Bols N. C., Mosser D. D. and Steels G. B. (1992) Temperature studies and recent advances with fish cells in vitro. Comp. Biochem. Physiol. 103A, 1-4.

Chen J. D., Yew F. H. and Li G. C. (1988) Thermal adaptation and heat shock response of tilapia ovary cells. J. Cell Physiol. 134, 189-199.

Chen S. N. and Kou G. H (1988) Establishment, characterization and application of 14 cell lines from warm-water fish. In Invertebrate and Fish Tissue Culture (Edited by Kuroda Y., Kurstak E. and Maramorosch K.), pp. 218-227. Japan Scientific Societies Press, Tokyo.

Collier N. C. and Schlesinger M. J. (1986) The dynamic state of heat shock proteins in chicken embryo fibroblast. J. Cell Biol. 103, 1495-1507.

Collier N. C., Heuser J., Levy M. A. and Schlesinger M. J. (1988) Ultrastructural and biochemical analysis of the stress granule in chicken embryo fibroblasts. J. Cell Biol. 106, 1131-1157.

Craig E. A. (1985) The heat shock response. CRC Crit. Rev. Biochem. 18, 239-280.

Dyer S. C., Dickson K. L. and Zimmerman E. G. (1991) Tissue-specific patterns of synthesis of heat-shock proteins and thermal tolerance of the fathead minnow (Pimephales promelas). Can. J. Zool. 69, 2021-2027.

Gedamu L., Culham B. and Heikkila J. J. (1983) Analysis of the temperature-dependent temporal pattern of heatshock-protein synthesis in fish cells. Biosci. Rep. 3, 647-658.

Heikkila J. J., Schultz G. A., Iatrou K. and Gedamu L. (1982) Expression of a set of fish genes following heat or metal ion exposure. J. biol. Chem. 237, 12000-12005.

Hightower L. E. and Renfro J. L. (1988) Recent application of fish cell culture to biomedical research. J. exp. Zool. 248, 290-302.

Hochstrasser D., Augsburger V., Pun T., Weber D., Pellegrini C. and Muller A. F. (1988) Methods for increasing the resolution of two-dimensional protein electrophoresis. Clin. Chem. 34, 166-170.

Imamoto N., Matsuoka Y., Kurihara T., Kohno K. and Miyagi M. (1992) Antibodies against 70-kDa heat shock cognate protein inhibit mediated nuclear import of karyophilic proteins. J. Cell Biol. 119, 1047-1061

Knauf U., Bielka H. and Gaestel M. (1992) Over-expression of the small heat-shock protein, hsp25, inhibits growth of Ehrlich ascites tumor cells. FEBS Lett. 309, 297-302.

Koban M., Graham G. and Prosser C. L. (1987) Induction of heat-shock protein synthesis in teleost hepatocytes: effects of acclimation temperature. Physiol. Zool. 60, 290-296.

Kothary R. K. and Candido E. P. M. (1982) Induction of a novel set of polypeptides by heat shock or sodium arsenite in cultured cells of rainbow trout, Salmo gairdnerii. Can. J. Biochem. 60, 347-355.

Kothary R. K., Burgess E. A. and Candido E. P. M. (1984a) The heat-shock phenomenon in cultured cells of rainbow trout hsp70 mRNA synthesis and turnover. Biochim. biophys. Acta 783, 137-143.

Kothary R. K., Burgess E. A. and Candido E. P. M. (1984b) 70-kilodalton heat-shock polypeptides from rainbow trout: characterization of cDNA sequences. Molec. Cell Biol. 4, 1785-1791. 
Ku C. C. and Chen S. N. (1991) Heat shock proteins in cultured gill cells Cyprinus carpio. Bull. Inst. Zool., Acad. Sin. 30, 319-330.

Ku C. C. and Chen S. N. (1992) Characterization of three cell lines derived from color carp Cyprinus carpio. J. Tiss. Cull. Meth. 14, 63-72.

Ku C. C., Chen S. N. and Kou G. H. (1992) Dynamic changes in the localization and quantity of heat shock proteins in a cultured fin cell line of color carp Cyprinus carpio. Bull. Inst. Zool., Acad. Sin. 31, 276-289.

Laemmli U. K. (1970) Cleavage of structural proteins during the assembly of the head of bacteriophage $T_{4}$. Nature, Lond. 227, 680-685.

Landry J., Chretien P., Lambert H., Hickey E. and Weber L. A. (1989) Heat shock resistance conferred by expression of the human hsp 27 gene in rodent cells. $J$. Cell Biol. 109, 7-15.

Liao T. H. (1975) Reversible inactivation of pancreatic deoxyribonuclease A by sodium dodecyl sulfate. J. biol. Chem. 250, 3831-3836.

Lindquist S. (1986) The heat-shock response. A. Rev. Biochem. 55, 1151-1191.

Margulis B. A., Antropova O. Yu. and Kharazova A. D. (1989) $70-\mathrm{kDa}$ heat-shock proteins from mollusc and human cell have common structural and functional domains. Comp. Biochem. Physiol. 94B, 621-623.

Misra S., Zafarullah M., Price-Haughey J. and Gedamu L. (1989) Analysis of stress-induced gene expression in fish cell lines exposed to heavy metals and heat shock. Biochim. biophys. Acta 1007, 325-333.

Mosser D. D., Heikkila J. J. and Bols N. C. (1986) Temperature ranges over which rainbow trout fibroblasts survive and synthesize heat-shock proteins. J. Cell Physiol. 128, 432-440.

Nover L., Sceare K. D. and Neumann D. (1983) Formation of cytoplasmic heat shock granules in tomato cell cultures and leaves. Molec. Cell Biol. 3, 1648-1655.

Oda S., Mitani H., Naruse K. and Shima A. (1991) Synthesis of heat shock proteins in the isolated fin of the medaka, Oryzias latipes, acclimatized to various temperatures. Comp. Biochem. Physiol. 98B, 587-591.

Pongratz I., Grant G. F. and Poellinger L. (1992) Dual role of the $90-\mathrm{kDa}$ heat shock protein hsp90 in modulating functional activities of the dioxin receptor. J. biol. Chem. 267, 13728-13734

Rossi J. M. and Lindquist S. (1989) The intracellular location of yeast heat-shock protein 26 varies with metabolism. J. Cell Biol. 108, $425-439$.

Rutledge P. S., Easton D. P. and Spotila J. R. (1987) Heat-shock proteins from the lungless salamanders Eurycea bislineata and Desmognathus ochrophaeus. Comp. Biochem. Physiol. 88B, 13-18.

Sanchez E. R., Toft D. O., Schlesinger M. J. and Pratt W. B. (1985) Evidence that the $90-\mathrm{kDa}$ phosphoprotein associated with the untransformed L-cell glucocorticoid receptor is a murine heat-shock protein. J. biol. Chem. 260, 12398-12401.

Smith D. F., Stensgard B. A., Welch W. J. and Toft D. O (1992) Assembly of progesterone receptor with heatshock proteins and receptor activation are ATP-mediated events. J. biol. Chem. 267, 1350-1356.

Stahl J., Wobus A. M., Ihrig S., Lutsch G. and Bielka H (1992) The small heat-shock protein hsp25 is accumulated in P19 embryonic stem cells of line BLC6 during differentiation. Differentiation 51, 33-37.

Sato M., Mitani H. and Shima A. (1990) Eurythermic growth and synthesis of heat-shock proteins of primary cultured goldfish cells. Zool. Sci. 7, 395-399.

Ullrich S. J., Robinson E. A., Law L. W., Willinghan M. and Appella E. (1986) A mouse tumor-specific transplantation antigen is a heat-shock-related protein. Proc. natn. Acad. Sci. U.S.A. 83, 3121-3125.

Welch W. J. (1992) Mammalian stress response: cell physiology, structure/function of stress proteins, and implications for medicine and disease. Physiol. Rev. 72, 1063-1081.

Wiech H., Buchner J., Zimmermann R. and Jakob U. (1992) Hsp90 chaperons protein folding in vitro. Nature, Lond. 238, 169-170.

Yoshimizu M., Kamei M., Dirakbusarakom S. and Kimura T. (1988) Fish cell lines: susceptibility to salmonid viruses. In Invertebrate and Fish Tissue Culture (Edited by Kuroda Y., Kurstak E. and Maramorosch K.), pp. 207-214. Japan Scientific Societies Press, Tokyo. 